\title{
A NONLINEAR STATISTICAL APPROACH FOR DAMPING UNCERTAINTY PROPAGATION IN STRUCTURAL DYNAMICS
}

\author{
B. TILIOUINE ${ }^{1}$, B. CHEMALI ${ }^{2}$
}

\begin{abstract}
The object of the present study is to investigate the influence of damping uncertainty and statistical correlation on the dynamic response of structures with random damping parameters in the neighbourhood of a resonant frequency. A Non-Linear Statistical model (NLSM) is successfully demonstrated to predict the probabilistic response of an industrial building structure with correlated random damping. A practical computational technique to generate first and second-order sensitivity derivatives is presented and the validity of the predicted statistical moments is checked by traditional Monte Carlo simulation. Simulation results show the effectiveness of the NLSM to estimate uncertainty propagation in structural dynamics. In addition, it is demonstrated that the uncertainty in damping indeed influences the system response with the effects being more pronounced for lightly damped structures, higher variability and higher statistical correlation of damping parameters.
\end{abstract}

Keywords: Uncertainty propagation, correlated damping, structural dynamics, sensitivity derivatives, Monte Carlo simulation, nonlinear statistical model.

\section{INTRODUCTION}

Damping is an important factor in the response analysis and design of dynamically sensitive structures. Furthermore, unlike other system parameters, damping does not refer to a single physical phenomenon and depends on a wide range of factors (e.g. [1], [2]) including vibration amplitudes, nature of structural resisting systems, nature of underlying damping mechanisms etc.

\footnotetext{
1 Prof., Ecole Nationale Polytechnique, Department of Civil Engineering, 10 Avenue H.Badi, 16200 Algiers, Algeria, e-mail: tiliouine_b@yahoo.fr

${ }^{2}$ PhD candidate., Ecole Nationale Polytechnique, Department of Civil Engineering, 10 Avenue H.Badi, 16200 Algiers, Algeria, e-mail: badar093@yahoo.fr
} 
This has been commonly addressed in structural design through the deterministic use of average damping values without specific attention to the uncertainty associated with this fundamental input parameter. However, for excitation frequencies close to the resonant frequencies, the sensitivity of structural response to damping becomes critical. Errors in the estimation of damping variability will generally result in large errors in the response uncertainty. The impact of large values of uncertainty and statistical correlation of damping parameters on accurate prediction of peak response of structures can be significant. This problem is of particular importance in relation to the dynamic response analysis of tall structures that rely on damping for their performance under wind vibrations (e.g. [1]) and earthquake ground motions (e.g. [3]). In order to provide additional information for practical applications in engineering design, this article presents the main results of a numerical investigation on the uncertainty of dynamic response of a typical building structure with correlated damping parameters using a Non-Linear Statistical approach. A Non-Linear Statistical Model (NLSM) is implemented to efficiently propagate damping uncertainty through dynamic analyses, to predict second order statistics for the probabilistic response of structures with correlated damping parameters. The significance of random damping with correlated parameters and its implications on the sensitivity of structural peak response in the neighbourhood of a resonant frequency are discussed in light of considerable ranges of damping uncertainties and correlation coefficients. In addition, the impact of statistical correlation of damping on the limits of approximation of the NLSM is investigated by means of the traditional Monte Carlo Simulation (MCS) technique.

\section{NON LINEAR STATISTICAL MODEL}

In the present study, the input random variables are conveniently arranged in an n-dimensional vector $\boldsymbol{c}=\left[c_{1}, \ldots, c_{n}\right]^{T}$ with mean values $\overline{\boldsymbol{c}}=\left[\bar{c}_{1}, \ldots, \bar{c}_{n}\right]^{T}$, and standard deviations $\sigma_{c}=\left[\sigma_{c 1}, \ldots, \sigma_{c n}\right]^{T}$.The response vector $\boldsymbol{X}=\boldsymbol{X}(\mathbf{c})$, is a function of the input vector random variables c, i.e. $\boldsymbol{X}$ is random field (e.g. [4]). The uncertainties in damping coefficients are propagated through the functional relationships that correlate with the response for determining the uncertainty of dynamic response estimates.

In order to implement uncertainty of damping in the dynamic analysis, recall that the matrix system of differential equations of motion governing the displacement vector $\boldsymbol{X}(\mathrm{t})$ at time " $\mathrm{t}$ ", of an $\mathrm{n}$ MDOF discretized dynamic system subjected to an external excitation vector $\boldsymbol{F}(\mathrm{t})$ can be written as: 


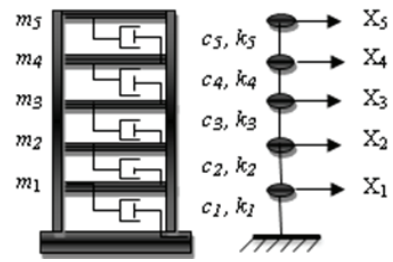

Fig. 1. Five story building example with random damping characteristics $\left(\bar{c}_{i}, \sigma_{c i}\right.$ and $\left.\rho_{\mathrm{c} i \mathrm{j}} ; \mathrm{i}, \mathrm{j}=1, \ldots, \mathrm{n}\right)$

$$
[M] \ddot{\boldsymbol{X}}+[C] \dot{\boldsymbol{X}}+[K] \boldsymbol{X}=\boldsymbol{F}(t)
$$

A physical system described by Eq. (2.1) and representative of a typical industrial building with rigid floors is shown in Fig. 1 , for $\mathrm{n}=5$. In this system $[M]$ and $[K]$ are deterministic. The damping matrix $[C]$ is of triangular form with coefficients depending linearly on the viscous damping coefficients $c_{i}$ according to the definition of its elements (e.g. [5]). In this work, the uncertainty in damping, represented by statistically correlated, randomly distributed damping coefficients, is propagated using a NLSM checked independently by the traditional MCS technique. The damping coefficients $c_{i}$ are assumed to be normally distributed with mean values $\bar{c}_{i}$ and standard deviations $\sigma_{c i}$. The validity of the normal distribution of damping and its probabilistic characteristics based on a full scale measurement of buildings under wind vibrations has been checked by [2]. Consider $\boldsymbol{X}$ as a function of $\mathbf{c}$ only and denote by $\boldsymbol{X}^{\boldsymbol{\theta}}=\boldsymbol{X}(\overline{\boldsymbol{c}})$, the value of $\boldsymbol{X}$ when $\mathbf{c}$ takes on its mean value $\overline{\boldsymbol{c}}$. Then the vector $\boldsymbol{X}$ can be expanded in a Taylor series about $\mathbf{c}=\overline{\mathbf{c}}$ as follows:

$$
\boldsymbol{X}(\boldsymbol{c})=\boldsymbol{X}(\overline{\boldsymbol{c}})+\sum_{i=1}^{n} \frac{\partial \boldsymbol{X}}{\partial c_{i}}\left(c_{i}-\bar{c}_{i}\right)+\sum_{j=1}^{n} \sum_{i=1}^{n} \frac{\left(c_{i}-\bar{c}_{i}\right)\left(c_{j}-\bar{c}_{j}\right)}{2 !} \frac{\partial^{2} \boldsymbol{X}}{\partial c_{i} \partial c_{j}}
$$

where the higher order terms have been neglected in the present case. Introducing first and second order sensitivity derivatives, $\xi_{i j}$ and $\eta_{i j}$ respectively

$$
\begin{array}{ll}
\xi_{i j}=\left(\partial X_{i} / \partial c_{j}\right)_{c_{k}=\bar{c}_{k}} & \text { for } \quad \mathrm{k}=1 \ldots \mathrm{n} \\
\eta_{i j}=\frac{\partial}{\partial c_{i}} \xi_{i j}=\left(\partial^{2} X_{i} / \partial c_{i} \partial c_{j}\right)_{c_{k}=\bar{c}_{k}} & \text { for } \quad \mathrm{k}=1 \ldots \mathrm{n}
\end{array}
$$

It can be shown (e.g [6], [7] ) that for a normal distribution of input variables $c$, the following approximations for the mean and variance of the output function $\boldsymbol{X}$ hold: 


$$
\bar{X}(c)=X(\bar{c})+\left.\frac{1}{2 !} \sum_{j=1}^{n} \sum_{i=1}^{n} \frac{\partial^{2} \boldsymbol{X}}{\partial c_{i} \partial c_{j}}\right|_{\bar{c} i, \bar{c} j} \rho_{i j} \sigma_{c i} \sigma_{c j}
$$

$$
\operatorname{Var}[\boldsymbol{X}]=\left.\left.\sum_{i}^{n} \sum_{j}^{n} \frac{\partial \boldsymbol{X}}{\partial c_{i}}\right|_{\bar{c} i} \frac{\partial \boldsymbol{X}}{\partial c_{j}}\right|_{\bar{c} j} \rho_{i j} \sigma_{c i} \sigma_{c j}+\frac{1}{2} \sum_{i=1}^{n} \sum_{j=1}^{n}\left(\left.\frac{\partial^{2} \boldsymbol{X}}{\partial c_{i} \partial c_{j}}\right|_{\bar{c} i, \bar{c} j} \sigma_{c i} \sigma_{c j}\right)^{2}+\frac{1}{2} \sum_{i=1}^{n} \sum_{j=1}^{n}\left(\left.\frac{\partial^{2} \boldsymbol{X}}{\partial c_{i} \partial c_{j}}\right|_{\bar{c} i, \bar{c} j} \rho_{i j} \sigma_{c i} \sigma_{c j}\right)^{2}
$$

Note in Eq. (2.6) that the second-order mean output, $\overline{\boldsymbol{X}}$, is not at the mean values of input $\overline{\boldsymbol{c}}$, i.e., $\bar{X} \neq \boldsymbol{X}(\bar{c})$. It is worth mentioning that the first terms of right hand sides of Eq. (2.5) and Eq. (2.6) represent a FO second moment method, whereas the right hand sides of Eq. (2.5) and Eq. (2.6) including all terms, represent a SO second moment method extended herein for examining uncertainty propagation of statistically correlated damping parameters. The methods are straightforward with the difficulty largely lying in computation of the sensitivity derivatives.

It should also be noted that the $\mathrm{ij}^{\text {th }}$ element of the Covariance matrix of the pair of random damping variables $\mathrm{c}_{\mathrm{i}}$ and $\mathrm{c}_{\mathrm{j}}$ is defined by $C O V_{i j}=\rho_{i j} \sigma_{c i} \sigma_{c j}$ where $\rho_{i j}=1$ if $\mathrm{i}=\mathrm{j}$

The elements of the main diagonal are the variance and are known from the assumed distribution law. The off diagonal elements contain the correlation $\rho_{\mathrm{ij}}$ between the various damping coefficients. Note that when the correlation coefficients $\rho_{i j}=0$ for $i \neq j$, the input random variables $\mathbf{c}$ are said to be uncorrelated whereas when $\rho_{i j}=1$ for $i \neq j$, they are said to be fully correlated. Various assumptions can be made regarding the partial correlations $\rho_{i j}$ between the various damping coefficients. However, we prefer to give this problem which is random in nature, a random solution. Once the variances and correlations of the damping coefficients are prescribed, a Monte Carlo simulation of damping coefficients generates a Gaussian distribution and a Covariance matrix whose Root Mean Square (RMS) of the off-diagonal elements converge to the RMS of prescribed values. The off-diagonal terms of the matrix thus generated are assumed to represent the correlation in the system. Note that the computer simulation of damping coefficients using the Monte Carlo simulation technique is based on a multivariate normal distribution with prescribed mean vector $\overline{\boldsymbol{c}}=\left[\bar{c}_{1}, \ldots, \bar{c}_{n}\right]^{T}$ and Covariance matrix $[\mathrm{COV}]$. It is worth noting that while the normal multivariate cumulative distribution function is not trivial to compute in high dimensions, [8], it is available in commonly used software packages such as Matlab. The sensitivity functions $\xi_{i j}$ are available by differentiation of Eq. (2.1) with respect to $c_{j}$ as follows:

$$
[M] \ddot{\xi}_{j}+[C] \dot{\xi}_{j}+[K] \xi_{j}=-\left(\partial[C] / \partial c_{j}\right) \dot{\boldsymbol{X}}
$$


The sensitivity functions $\eta_{i j}$ are available by differentiation of Eq. (2.7) with respect to $c_{j}$ as follows:

$$
[M] \boldsymbol{\eta}_{j}+[C] \boldsymbol{\eta}_{j}+[K] \boldsymbol{\eta}_{j}=-\left(\frac{\partial^{2}[C]}{\partial c_{j}^{2}}\right) \dot{\boldsymbol{X}}-2 \frac{\partial[C]}{\partial c_{j}} \dot{\boldsymbol{\xi}}_{j}
$$

The left sides of Eq. (2.7) and Eq. (2.8) are identical to those of Eq. (2.1), and the right sides can be interpreted as fictitious forcing vectors.

In the case of general loading $\boldsymbol{F}(t)$, the right sides of Eq. (2.7) and Eq. (2.8), can be obtained from the time derivative $\dot{\boldsymbol{X}}$ of the response $\boldsymbol{X}^{\boldsymbol{0}}=\boldsymbol{X}(\overline{\boldsymbol{c}})$, the value of $\boldsymbol{X}$ when $\mathbf{c}$ takes on its mean value $\overline{\boldsymbol{c}}$. For systems with large numbers of degrees of freedom, the vector $\boldsymbol{X}^{\boldsymbol{0}}$ can be computed by solving Eq. (2.1) with nominal damping $c_{j}=\bar{c}_{j}$ using mode superposition analysis. Alternatively, the vectors $\boldsymbol{X}$ and $\dot{X}$ can be obtained systematically by using step by step integration methods of structural dynamics (e.g. [5]). Thus, to obtain the vectors $\xi_{j}(\mathrm{j}=1$...n), Eq. (2.1) must be solved first with the forcing vector $\boldsymbol{F}(t)$ after which Eq. (2.8) is solved, n times. Thus, the global bulk of computations involve essentially, a computer simulation for the evaluation of the Covariance matrix $[\mathrm{COV}]$, then, the solution of Eq. (2.1) for $\boldsymbol{X}^{0}, \dot{\boldsymbol{X}}^{0}$ and finally the solution for $\xi_{j}$, n times.

In order to obtain $\boldsymbol{\eta}_{j}(\mathrm{j}=1 \ldots \mathrm{n})$, Eq. (2.7) must first be solved with the fictitious forcing vector $-\left(\partial[C] / \partial c_{j}\right) \dot{\boldsymbol{X}}$ after which Eq. (2.8) is solved, $\mathrm{n}$ times.

\section{NUMERICAL EXAMPLE}

A numerical example utilizing a typical industrial building, modeled as a lumped mass system, is considered to predict uncertainty propagation and examine quantitatively the influence of large values of damping uncertainty and statistical correlation on the overall response under dynamic excitation induced by a rotating machine under resonant condition.

The structural system shown in Fig. 1 is taken as a basic model for the computations. For the sake of clarity, the lumped mass at each floor, the inter-story stiffness and the mean value of the inter-story damping constant between each level are kept constant in this study, although different values could be used as input. The lumped mass at each floor is equal to $\mathrm{m}_{1}=\mathrm{m}_{2}=\mathrm{m}_{3}=\mathrm{m}_{4}=\mathrm{m}_{5}=150 \mathrm{t}$ and the inter-story stiffness between each level is such that $\mathrm{k}_{1}=\mathrm{k}_{2}=\mathrm{k}_{3}=\mathrm{k}_{4}=\mathrm{k}_{5}=210^{*} 10^{3} \mathrm{KN} / \mathrm{m}$. The mean values $\vec{c}$ of the inter-story damping constants, examined in this study were (in ascending order) $\bar{c}$ $=197.19, \bar{c}=394.37, \bar{c}=778.74, \bar{c}=1577.48$ and $\bar{c}=1971.86 \mathrm{KN} / \mathrm{m} / \mathrm{s}$ (in the example considered, these values correspond to $0.5 \%, 1 \%, 2 \%, 3 \%, 5 \%$ of critical damping respectively). Each value of 
the damping constant was assigned a coefficient of variation $\left(\mathrm{Cov}=\sigma_{c} / \bar{c}\right)$ that varied from $10 \%$ to $60 \%$ with uniform increments of $10 \%$.The results are presented for two extreme values of coefficient of correlation i.e. ( $\rho_{\mathrm{cij}}=0$ in case of uncorrelated damping parameters and $\rho_{\mathrm{cij}}=1$ in case of fully correlated damping parameters). The dynamic excitation resulting from a rotating machine, applied at the first story is represented by a harmonic function of amplitude $\mathrm{F}=1400 \mathrm{KN}$ and frequency $\Omega=31.09 \mathrm{rad} / \mathrm{s}$ corresponding to the second resonant frequency of the structural system.

\section{SAMPLE RESULTS AND DISCUSSION}

In Table 1, the standard deviations of peak story displacement for several combinations of mean damping values $\bar{c}_{i}$ and corresponding coefficients of variation are (for the sake of clarity) presented for the two extreme cases of uncorrelated and fully correlated damping parameters. The results obtained from the application of the NLS Model are systematically compared with the corresponding results derived from the traditional MCS method.

It is to be noted that both methods are in acceptable agreement up to Cov of damping values less than or equal to $30 \%$ in the case of uncorrelated damping parameters and up to Cov of damping less than $20 \%$ in the case of perfectly correlated damping. Both methods are in excellent agreement up to Cov of damping values less than or equal to $30 \%$ in the uncorrelated case of damping parameters (respectively $20 \%$ for the fully correlated case). If the uncertainty about damping is such that larger Cov values should be considered, the assumption of Gaussian distribution should be abandoned in order to prevent negative values of c, i.e. to ensure that damping must be always positive.

As a matter of fact, it is clear that, if the Cov of $\mathrm{c}$ is large (e.g: 40\%), the errors between the methods are considerably higher than in the other cases and the probability of choosing for $\mathrm{c}$ a negative value cannot be neglected. If this happens even a few times during the MCS, a large dispersion in the computed response is very likely to occur. This situation is typical in presence of light damping and large values of Cov of damping (in the example considered, $\bar{c}==197.19$ $\mathrm{KN} / \mathrm{m} / \mathrm{s}$ corresponds to five thousands of critical damping).

It is also observed that the coefficient of variation of the peak story displacement response computed using the NLS Model is equal to the coefficient of variation of damping for the case of perfectly correlated damping parameters whereas it is only half this value in the uncorrelated case, 
Table 1. Comparison of Non-Linear Statistical Model (NLSM) with Monte Carlo simulation (MCS) method for uncorrelated and perfectly correlated damping parameters.

\begin{tabular}{|c|c|c|c|c|c|c|c|c|c|c|c|}
\hline \multirow[t]{2}{*}{$\begin{array}{c}\text { Flo } \\
\text { orN } \\
\circ\end{array}$} & \multicolumn{2}{|c|}{$\begin{array}{c}\text { Standard deviations } \\
\text { of response }(\rho \mathrm{c} i, j=0)\end{array}$} & \multicolumn{2}{|c|}{$\begin{array}{l}\text { Standard deviations } \\
\text { of response }(\rho c \mathrm{i}, \mathrm{j}=1)\end{array}$} & \multirow[t]{2}{*}{$\begin{array}{l}\text { Confidence } \\
\text { interval on ci } \\
(\%)\end{array}$} & \multirow{2}{*}{$\begin{array}{c}\text { Mean values } \\
\text { of Damping } \\
\bar{c}_{i}\end{array}$} & \multirow{2}{*}{$\sigma_{c i} / \bar{c}_{i}$} & \multicolumn{3}{|c|}{ Coefficients of variation } & \multirow{2}{*}{$\begin{array}{l}/ \bar{X}_{i} \\
\mathrm{CS}) \\
\rho \mathrm{c} \mathrm{ij}=1(\%)\end{array}$} \\
\hline & $(\mathrm{cm})$ & Error $(\%)$ & $(\mathrm{cm})$ & Error $(\%)$ & & & & $\rho c \mathrm{ij}=0$ & $\rho c \mathrm{ij}=1$ & $\rho c \mathrm{ij}=0(\%)$ & \\
\hline 1 & 1,86 & 17,42 & 18,99 & 84,92 & \multirow{5}{*}{98,758} & \multirow{5}{*}{197,19} & \multirow{5}{*}{0,4} & 0,22 & 0,40 & 0,25 & 2,99 \\
\hline 2 & 2,44 & 17,62 & 24,87 & 84,92 & & & & 0,22 & 0,40 & 0,26 & 3,02 \\
\hline 3 & 1,33 & 17,42 & 13,59 & 84,92 & & & & 0,22 & 0,40 & 0,26 & 3,02 \\
\hline 4 & 0,69 & 17,08 & 7,08 & 84,91 & & & & 0,22 & 0,40 & 0,25 & 2,99 \\
\hline 5 & 2,25 & 17,63 & 22,86 & 84,92 & & & & 0,22 & 0,41 & 0,26 & 3,03 \\
\hline 1 & 0,59 & 6,82 & 2,04 & 48,60 & \multirow{5}{*}{99,911} & \multirow{5}{*}{394,37} & \multirow{5}{*}{0,3} & 0,16 & 0,30 & 0,17 & 0,66 \\
\hline 2 & 0,78 & 6,90 & 2,68 & 48,80 & & & & 0,16 & 0,30 & 0,17 & 0,67 \\
\hline 3 & 0,43 & 6,89 & 1,46 & 48,69 & & & & 0,16 & 0,30 & 0,17 & 0,67 \\
\hline 4 & 0,22 & 5,63 & 0,76 & 48,32 & & & & 0,16 & 0,30 & 0,17 & 0,66 \\
\hline 5 & 0,72 & 6,75 & 2,47 & 48,72 & & & & 0,16 & 0,30 & 0,17 & 0,68 \\
\hline 1 & 0,23 & 2,67 & 0,59 & 23,68 & \multirow{5}{*}{99,994} & \multirow{5}{*}{788,74} & \multirow{5}{*}{0,25} & 0,13 & 0,24 & 0,14 & 0,34 \\
\hline 2 & 0,31 & 4,45 & 0,80 & 25,23 & & & & 0,13 & 0,25 & 0,14 & 0,35 \\
\hline 3 & 0,17 & 2,14 & 0,44 & 25,36 & & & & 0,14 & 0,25 & 0,14 & 0,35 \\
\hline 4 & 0,09 & 1,82 & 0,22 & 23,77 & & & & 0,13 & 0,24 & 0,14 & 0,34 \\
\hline 5 & 0,29 & 4,93 & 0,74 & 26,03 & & & & 0,13 & 0,26 & 0,14 & 0,35 \\
\hline 1 & 0,12 & 1,33 & 0,25 & 8,28 & \multirow{5}{*}{99,999} & \multirow{5}{*}{1577,48} & \multirow{5}{*}{0,2} & 0,09 & 0,18 & 0,11 & 0,23 \\
\hline 2 & 0,16 & 2,55 & 0,34 & 9,32 & & & & 0,10 & 0,20 & 0,11 & 0,23 \\
\hline 3 & 0,09 & 1,04 & 0,19 & 9,96 & & & & 0,11 & 0,20 & 0,11 & 0,23 \\
\hline 4 & 0,05 & 0,85 & 0,09 & 8,06 & & & & 0,10 & 0,18 & 0,11 & 0,23 \\
\hline 5 & 0,15 & 3,76 & 0,32 & 9,45 & & & & 0,11 & 0,21 & 0,11 & 0,23 \\
\hline 1 & 0,04 & 0,80 & 0,07 & 1,56 & \multirow{5}{*}{$\approx 100$} & \multirow{5}{*}{1971,86} & \multirow{5}{*}{0,1} & 0,04 & 0,08 & 0,05 & 0,10 \\
\hline 2 & 0,05 & 0,14 & 0,09 & 1,57 & & & & 0,05 & 0,10 & 0,05 & 0,10 \\
\hline 3 & 0,03 & 0,71 & 0,05 & 1,03 & & & & 0,06 & 0,11 & 0,05 & 0,10 \\
\hline 4 & 0,01 & 0,83 & 0,03 & 1,57 & & & & 0,05 & 0,08 & 0,05 & 0,10 \\
\hline 5 & 0,05 & 0,98 & 0,09 & 2,08 & & & & 0,06 & 0,11 & 0,05 & 0,10 \\
\hline
\end{tabular}

regardless of the mean damping values considered. Similar trends are observed for results obtained using the MCS method for Cov of damping values less than $20 \%$.

In figures 2 and 3, the standard deviation of building response at the second floor (corresponding herein to the maximum floor displacement) as function of Cov of damping is presented for two different mean values of damping using a Linear Statistical Model (LSM) and NLSM. It is seen that the uncertainty in damping influences the system response. Depending on the mean value of damping, the effects are more pronounced for higher variability and higher statistical correlation of damping parameters. If the uncertainty about damping is such that larger Cov values should be considered, the LSM becomes inadequate and higher order statistics based on second order sensitivity derivatives should be considered.

In figures 4 and 5 , the standard deviation of building responses with light damping $(\bar{c}=394.37$ $\mathrm{KN} / \mathrm{m} / \mathrm{s}$ ) at the second floor is presented for the LSM, NLSM model and MCS for the two cases of uncorrelated and perfectly correlated damping coefficients. The results suggest that differences in standard deviation of building response obtained using these methods are insignificant for values of Cov of damping up to the $20 \%$ and $33 \%$ limiting values of Cov of damping. However, for larger values, the errors for the NLSM in comparison with the MCS method increase concomitantly with 
an increase in Cov of damping. Moreover, it should be noted that a large dispersion in results between the LSM, NLSM and the traditional MCS method is observed for dynamic systems with light damping, large values of damping variability and high statistical correlation. In such cases, a distribution different from the normal is likely to give more realist results.

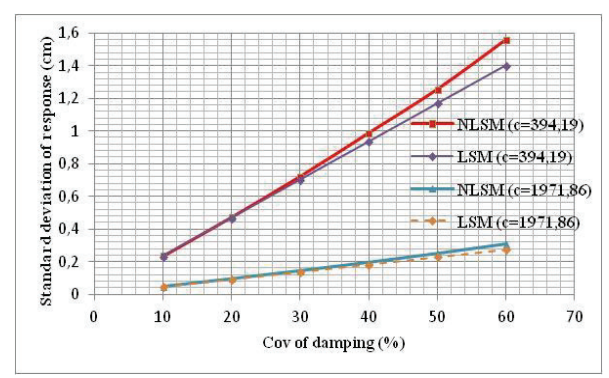

Fig. 2. Comparison of standard deviation of response $\left(\sigma_{X_{2}}\right)$ between LSM \& NLSM models at the $2^{\text {nd }}$ floor for different damping values $\left(\rho_{\mathrm{c} i \mathrm{j}}=0\right)$

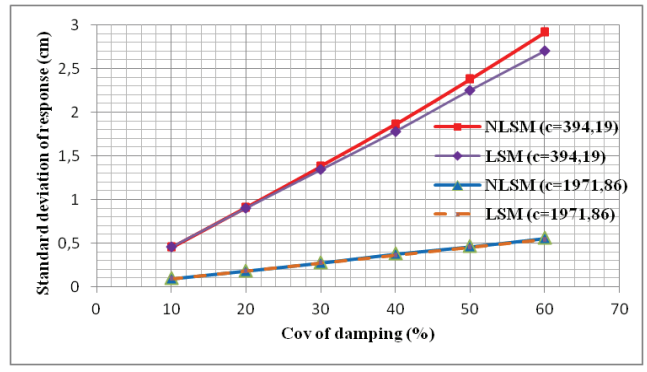

Fig. 3. Comparison of standard deviation of response $\left(\sigma_{X_{2}}\right)$ between LSM \& NLSM models at the $2^{\text {nd }}$ floor for different damping values $\left(\rho_{\mathrm{c} \text { ij }}=1\right)$

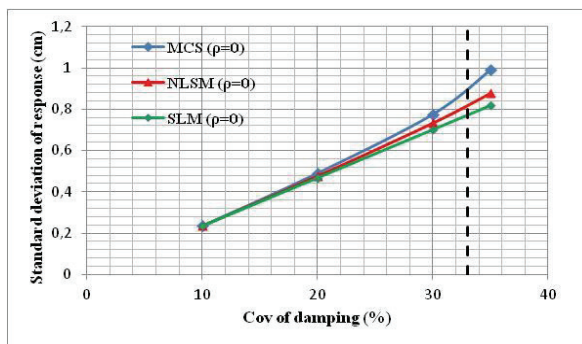

Fig. 4. Comparison of $\sigma_{X_{2}}$ between LSM, NLSM and MCS methods for light damping $\left(\rho_{\mathrm{c} i \mathrm{j}}=0\right)$

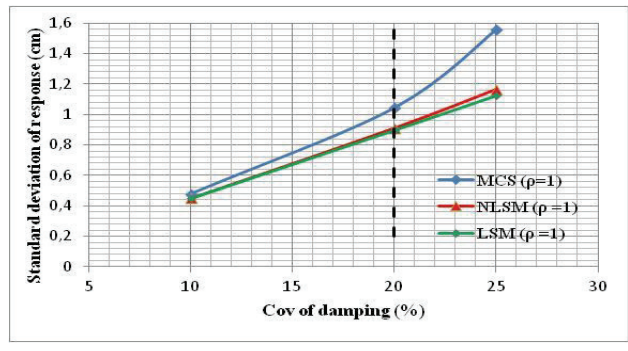

Fig. 5. Comparison of $\sigma_{X_{2}}$ between LSM, NLSM and MCS methods for light damping $\left(\rho_{\mathrm{c} i \mathrm{j}}=1\right)$

\section{CONVERGENCE AND TIMING CONSIDERATIONS}

A stochastic analysis with the traditional MCS method of $\mathrm{N}$ runs can be computationally expensive, especially for dynamic systems with large number of DOF. In the example presented here, this number was fixed at one thousand five hundred $(\mathrm{N}=1500)$ in the case of uncorrelated damping coefficients, [9], while in the case of perfectly correlated damping the number of iterations was set at four thousand $(\mathrm{N}=4000)$ in according with the progressive results obtained for the mean response estimate, its estimated variance (and hence its confidence interval) as a function of the number of samples. Typical convergence of these two response estimates with increasing sample size is illustrated in figures 6 and 7 respectively. In other cases, however, the slow convergence of 
statistical processes may require even more iterations. The savings in computer time achieved with LSM and NLSM become quite evident. In the present study, with five random input variables and five random output functions, the approximate statistical moment methods are very efficient; the LSM model requires approximately the computational equivalent of only five (05) analysis runs while the NLSM model requires approximately the computational equivalent of ten (10) analysis runs. Note that the CPU time associated with the LSM and NLSM model is essentially due to the calculation of the sensitivity derivatives functions.

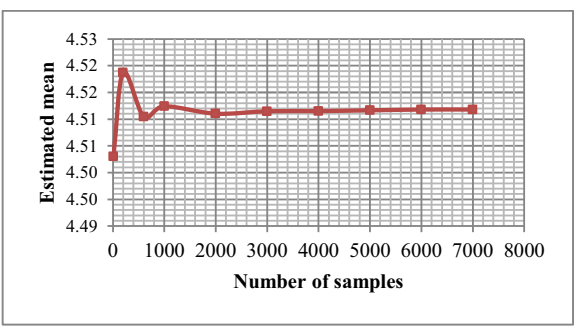

Fig. 6. Convergence of mean estimate with increasing sample size $\left(\rho_{\mathrm{c} \text { ij }}=1\right)$.

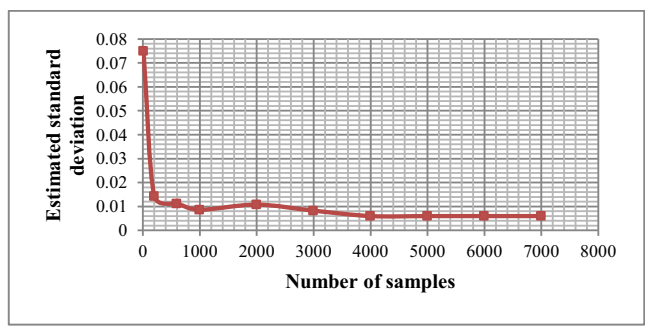

Fig. 7. Convergence of standard deviation estimate of mean with increasing sample size $\left(\rho_{\mathrm{c} i \mathrm{j}}=1\right)$.

\section{SUMMARY AND CONCLUSIONS}

This paper investigated the significance of damping variability and statistical correlation of damping parameters on the dynamic response of building structures in the neighbourhood of a resonant frequency.

The present results represent an implementation of a Non Linear Statistical Model and the traditional Monte Carlo Simulation technique for uncertainty propagation to predict second order statistics of peak response for structural dynamics problems with correlated random damping. A simple computational procedure calculating the sensitivity derivatives was employed and the validity of the models was assessed by comparison with statistical moments generated through independent Monte Carlo simulations for different degrees of damping correlation. Satisfactory agreement has been obtained up to Cov of damping values less than or equal $30 \%$ in the case of uncorrelated damping parameters and up to Cov of damping less than $20 \%$ in the case of perfectly correlated damping. Both methods are in excellent agreement up to Cov of damping values less than or equal $10 \%$. The analytical developments presented herein are applicable for different forms of damping and other parameters. Collectively, these results demonstrate the possibility of an effective approach to treat input parameters uncertainty and its propagation through structural 
dynamics analysis without large numbers of samples for both uncorrelated and correlated system parameters. Furthermore, the importance of damping uncertainty and the crucial role of statistical correlation of damping coefficients for accurate estimates of dynamic response under resonant conditions are demonstrated.

\section{REFERENCES}

1. A. Kareem, K. Gurley, "Damping in structures: evaluation and treatment of uncertainty", Journal of Wind Engineering \& Industrial Aerodynamics 59: 131-157, 1996.

2. J. Q. Fang, Q. S. Li, A. P. Jeary, D. K. Liu, "Damping of tall buildings: its evaluation and probabilistic characteristics", Structural Design of Tall Buildings 8: 145-153, 1999.

3. T. Mochio, M. Kondo, H. Sekiya, and H. Ibe, Stochastic seismic response analysis of structures with uncertain parameters. Mitsubishi Tech. Bull. 198, Mitsubishi Heavy Industries. Ltd, Tokyo. 1992

4. E. Vanmarcke, M. Shinozuka, S. Nakagiri, G. I. Schueller, M. Grigoriu, "Random fields and stochastic finite elements", Structural Safety 3: 143-166, 1986.

5. R. W. Clough, J. Penzien, "Dynamics of Structures". third ed. New York: Computers and Structures, 2003.

6. M.E. Harr, "Reliability based design in civil engineering". New York: Dover Publications, 1997.

7. J. R. Benjamin, C. A. Cornell, "Probability, Statistics, and Decision for Civil Engineers". New York: Dover Publications, 2014.

8. A. Genz, "Numerical computation of multivariate normal probabilities", Journal of Computational and Graphical Statistics 1:27-28, 1992.

9. B. Tiliouine, and B. Chemali, "On the Sensitivity of Dynamic Response of Structures with Random Damping”, Proc. 21st . French Congress on Mechanics, Bordeaux, France 2013. 


\section{LIST OF FIGURES AND TABLES:}

Fig. 1. Five story building example with random damping characteristics $\left(\bar{c}_{i}, \sigma_{c i}\right.$ and $\left.\rho_{\mathrm{c} i \mathrm{j}} ; \mathrm{i}, \mathrm{j}=1, . ., \mathrm{n}\right)$.

Rys. 1. Przykład pięciopiętrowego budynku z losową charakterystyką thumienia $\left(\bar{c}_{i}, \sigma_{c i}\right.$ and $\left.\rho_{\mathrm{c} \text { ij }} ; \mathrm{i}, \mathrm{j}=1, . ., \mathrm{n}\right)$.

Fig. 2. Comparison of standard deviation of response $\left(\sigma_{X_{2}}\right)$ between LSM and NLSM models at the $2^{\text {nd }}$ floor for different damping values $\left(\rho_{\mathrm{c} i \mathrm{j}}=0\right)$.

Rys. 2. Porównanie standardowego odchylenia odpowiedzi $\left(\sigma_{X_{2}}\right)$ w modelach LSM i NLSM na drugim piętrze dla różnych wartości thumienia $\left(\rho_{\mathrm{c} i \mathrm{j}}=0\right)$.

Fig. 3. Comparison of standard deviation of response $\left(\sigma_{X_{2}}\right)$ between LSM and NLSM models at the $2^{\text {nd }}$ floor for different damping values $\left(\rho_{\mathrm{c} i \mathrm{j}}=1\right)$.

Rys. 3. Porównanie standardowego odchylenia odpowiedzi $\left(\sigma_{X_{2}}\right)$ w modelach LSM i NLSM na drugim piętrze dla różnych wartości tłumienia $\left(\left(\rho_{\mathrm{c} i \mathrm{j}}=1\right)\right.$.

Fig. 4. Comparison of $\sigma_{X_{2}}$ between LSM, NLSM and MCS method for light damping $\left(\rho_{\mathrm{c} \text { ij }}=0\right)$.

Rys. 4. Porównanie $\sigma_{X_{2}}$ w metodach LSM, NLSM, SDEMC i MCS dla lekkiego thumienia $\left(\rho_{\mathrm{c} i \mathrm{j}}=0\right)$.

Fig. 5. Comparison of $\sigma_{X_{2}}$ between LSM, NLSM and MCS method for light damping $\left(\rho_{\mathrm{c} i \mathrm{j}}=1\right)$.

Rys. 5. Porównanie $\sigma_{X_{2}}$ w metodach LSM, NLSM, SDEMC i MCS dla lekkiego thumienia $\left(\rho_{\mathrm{c} i \mathrm{j}}=1\right)$.

Fig. 6. Convergence of mean estimate with increasing sample size $\left(\rho_{\mathrm{c} i \mathrm{j}}=1\right)$.

Rys. 6. Zbieżność średnich szacunków przy rosnącym rozmiarze próbki $\left(\rho_{\mathrm{c} i \mathrm{j}}=1\right)$.

Fig. 7. Convergence of standard deviation estimate of mean with increasing sample size $\left(\rho_{\mathrm{c} i j}=1\right)$.

Rys. 7. Zbieżność szacunków odchylenia standardowego średniej przy rosnącym rozmiarze próbki $\left(\rho_{\mathrm{c} i j}=1\right)$.

Table 1. Comparison of Non-Linear Statistical Model (NLSM) with Monte Carlo simulation (MCS) method for uncorrelated and perfectly correlated damping parameters.

Tabela 1. Porównanie Nieliniowego Modelu Statystycznego (NLSM) z symulacją Monte Carlo (MCS) dla nieskorelowanych oraz idealnie skorelowanych parametrów thumienia. 


\section{NIELINIOWE MODELOWANIE STATYSTYCZNE NIEPEWNOŚCI TLUMIENIA W DYNAMICE KONSTRUKCYJNEJ}

Stowa kluczowe: thumienie skorelowane, niepewność odpowiedzi dynamicznej, symulacja Monte Carlo, nieliniowy model statystyczny.

\section{STRESZCZENIE:}

Nieliniowy Model Statystyczny (NLSM) jest opracowany, aby skutecznie rozpowszechniać niepewność tłumienia w analizach dynamicznych, w celu przewidywania statystyki drugiego rzędu dla probabilistycznej odpowiedzi konstrukcji ze skorelowanymi parametrami thumienia.

Waga thumienia losowego ze skorelowanymi parametrami oraz ich wpływ na wrażliwość szczytowej odpowiedzi konstrukcyjnej, omawiane są w świetle znaczących zakresów niepewności thumienia oraz współczynników korelacji. Dodatkowo, wpływ korelacji statystycznej thumienia na granice przybliżenia Liniowego Modelu Statystycznego (LSM) oraz na NLSM badany jest za pomocą Symulacji Monte Carlo.

\section{WPROWADZENIE}

Tłumienie jest ważnym czynnikiem w analizie odpowiedzi oraz projektowaniu dynamicznie wrażliwej konstrukcji. Odnoszono się do tego powszechnie w projektach konstrukcyjnych, poprzez deterministyczne wykorzystanie średnich wartości tłumienia, bez szczególnej uwagi na niepewność związaną z tym podstawowym parametrem wejściowym. Jednakże, dla częstotliwości wzbudzenia w pobliżu częstotliwości rezonansowych, wrażliwość odpowiedzi konstrukcyjnej na tłumienie staje się krytyczna. Wpływ wysokich wartości niepewności tłumienia oraz korelacji statystycznej na dokładne przewidywania szczytowej odpowiedzi konstrukcyjnej, może być wysoki. Ten problem ma szczególne znaczenie w odniesieniu do analizy odpowiedzi dynamicznej wysokich budynków, które opierają się na thumieniu przy drganiach od wiatru (np. [1], [2]) oraz ruchach gruntu w przypadku trzęsień ziemi (np. [3]).

\section{WYNIKI LICZBOWE I DYSKUSJA}

Aby dostarczyć dodatkowe informacje do praktycznego zastosowania w projektach konstrukcyjnych, niniejszy artykuł prezentuje główne wyniki liczbowego dochodzenia w kwestii niepewności odpowiedzi dynamicznej pięciopiętrowego budynku ze skorelowanymi parametrami tłumienia, wykorzystując podejście Statystyki Nieliniowej, częstotliwość wzbudzenia wynikającą z drgań maszyny obrotowej, zastosowanej na pierwszym piętrze, odpowiadającą drugiej częstotliwości rezonacyjnej konstrukcji. Główne wyniki symulacji są przedstawione na rysunkach 1, 2, 3 i 4.

$\mathrm{Na}$ rys. 1 i 2 , standardowe odchylenie odpowiedzi budynku na 2 piętrze $\sigma_{X_{2}}$ (odpowiadające niniejszym maksymalnemu przemieszczeniu piętra) jako funkcja Cov (kowariancji) tłumienia jest zaprezentowana dla różnych średnich wartości tłumienia, przy wykorzystaniu zarówno LSM, jak i NLSM. Widać, że niepewność thumienia wpływa na odpowiedź systemu. W zależności od średniej wartości tłumienia, efekty są bardziej widoczne przy większej zmienności parametrów thumienia. Jeśli niepewność thumienia jest taka, że większe wartości Cov powinny być rozważone, LSM staje się niewystarczające i wykorzystana powinna zostać statystyka wyższego rzędu oparta na pochodnych wrażliwości drugiego rzędu (np. [4]). 
$\mathrm{Na}$ rys. 3 i 4, standardowe odchylenie odpowiedzi budynku dla lekkiego thumienia $(\bar{c}=394.37 \mathrm{KN} / \mathrm{m} / \mathrm{s})$ zaprezentowane jest dla metod LSM, NLSM oraz MCS, dla dwóch skrajnych przypadków, nieskorelowanych i doskonale skorelowanych współczynników tłumienia. Wyniki sugerują, że różnice w odchyleniu standardowych odpowiedzi budynku, otrzymane poprzez te metody, są nieistotne dla wartości Cov tłumienia do $20 \%$ oraz $33 \%$ wartości granicznych Cov tłumienia. Jednakże, dla większych wartości, błędy obu metod, LSM i NLSM, w odniesieniu do metody MCS, wzrastają wraz ze wzrostem Cov tłumienia. Co więcej, należy zauważyć, że duży rozrzut pomiędzy LSM, NLSM a tradycyjną metodą MCS, jest obserwowany dla systemów dynamicznych z lekkim thumieniem, wysokimi wartościami zmienności tłumienia oraz wysoką korelacją statystyczną. W takich przypadkach, rozkład różny od normalnego, prawdopodobnie da bardziej realistyczne rezultaty (np. [5]).
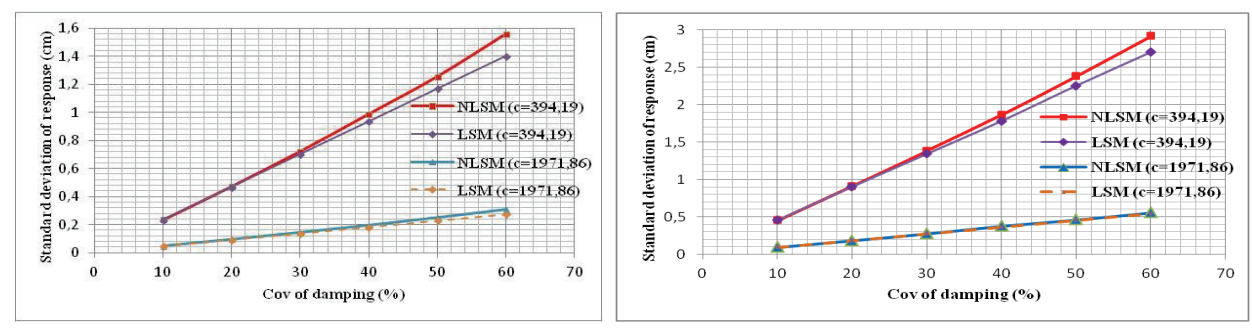

Rys. 1. Porównanie $\sigma_{X_{2}}$ wykorzystując modele LSM i NLSM dla różnych, średnich wartości tłumienia ( przypadek $\rho_{\mathrm{c}}$ $\mathrm{ij}=0)$

Rys. 2. Porównanie $\sigma_{X_{2}}$ wykorzystując modele LSM i NLSM dla różnych, średnich wartości thumienia ( przypadek $\rho_{\mathrm{c}}$ ij $=1$ )

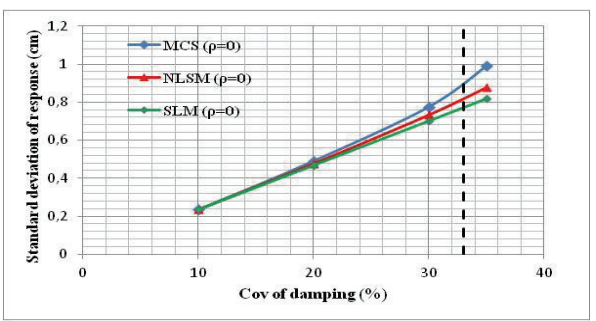

Rys. 3. Porównanie $\sigma_{X_{2}}$ w metodach LSM, NLSM i MCS dla thumienia lekkiego (przypadek $\rho_{\mathrm{c} \text { ij }}=0$ )

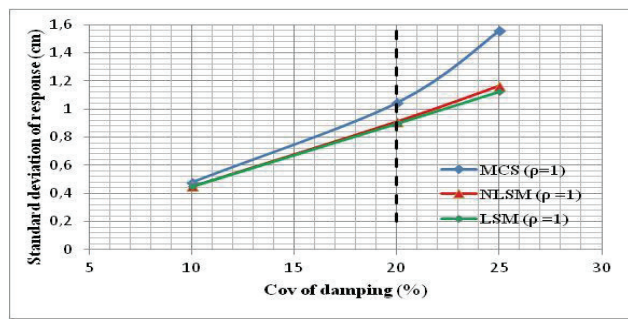

Rys. 4. Porównanie $\sigma_{X_{2}}$ w metodach LSM, NLSM i MCS dla thumienia lekkiego (przypadek $\rho_{\mathrm{c} \text { ij }}=1$ )

\section{Podsumowanie}

Niniejsza praca bada istotność zmienności tłumienia oraz statystycznej korelacji odpowiedzi dynamicznej konstrukcji budynków MDOF w warunkach częstotliwości rezonansowej, wykorzystując zarówno Liniowe, jak i Nieliniowe Modele Statystyczne do rozpowszechniania niepewności thumienia. Wyniki liczbowe otrzymane z zastosowania tych metodologii na typową konstrukcję budynku przemysłowego zostały sprawdzone przez niezależną MCS i uzyskane 
zostało satysfakcjonujące porozumienie co do Cov wartości thumienia niższej lub równej $30 \% \mathrm{w}$ przypadku nieskorelowanych parametrów thumienia i Cov niższej niż 20\%, w przypadku doskonale skorelowanego thumienia. Obie metody są doskonale zgodne z Cov (kowariancją) wartości thumienia mniejszą lub równą 10\%. Rozważania analityczne prezentowane w pracy mają zastosowanie do innych parametrów systemu. Co więcej, wykazane są waga niepewności thumienia oraz kluczowa rola korelacji statystycznej współczynników thumienia dla dokładnego oszacowania odpowiedzi dynamicznej w warunkach rezonansowych.

\section{LITERATURA}

1. A. Kareem, K. Gurley, "Damping in structures: evaluation and treatment of uncertainty", Journal of Wind Engineering \& Industrial Aerodynamics 59: 131-157, 1996.

2. J. Q. Fang, Q. S. Li, A. P. Jeary, D. K. Liu, "Damping of tall buildings: its evaluation and probabilistic characteristics", Structural Design of Tall Buildings 8: 145-153, 1999.

3. B. Tiliouine and M., Belghenou, The significance of damping variability and its effects on seismic response of building structures. International Conference on Earthquake Engineering. (SE- 50EEE). Skopje. Macedonia, 2013.

4. M.E. Harr, "Reliability based design in civil engineering" New York: Dover Publications, 1997.

5. B. Chemali, B. Tiliouine, "Second order statistics of dynamic response of structures using Gamma distributed damping parameters", World Academy of Science, Engineering and Technology 9: 220-226, 2015. 